\title{
The influence of downy mildew tolerance of grape varieties on the biosynthesis of stilbenes in callus as potential sources of bioactive substances*
}

\author{
Eugene Lutsky, Svyatoslav Fedorovich, Vadim Vyalkov, and Maria Sundyreva** \\ Federal State Budget Scientific Institution «North Caucasian Federal Scientific Center of \\ Horticulture, Viticulture, Wine-making», 39 str. 40 Let Pobedy, Krasnodar, 350901, Russia
}

\begin{abstract}
Stilbenes represent a considerable practical interest in relation to their benifits to the human health. Callus culture of the grape, which is a natural producer of stilbenes, can serve as an effective source of these compounds. Grape's resistance to biotic environmental stress conditions is associated with the synthesis and conversion of stilbenes, therefore the aim of the current study was to determine an interrelation between the tolerance of grape varieties to downy mildew and stilbene biosynthesis in the callus culture. Obtained results showed that there was no link between variety's tolerance to downy mildew and content of stilbenes, chalcones and phenoloxydising enzymes in callus. Presence of the stress impact is a necessary condition for the initiation of the variety-specific synthesis of stilbenes. Callus of varieties, in which stilbenes content was higher, was characterized by a lowered expression of the chalcone synthase and chalcone isomerase relative to expression of genes of the stilbene synthase and phenylalanine ammonia liase, which confirms an interrelation between reduced competition for the substrate between two biosynthesis branches of chalcones and stilbenes with production of the latter.
\end{abstract}

\section{Introduction}

Plants are indispensable sources of many important compounds to a human health. Berry skin, seeds, leaves, shoots, root hairs contain flavonoids (anthocyanins, proanthocyanidins), derivatives of the stilbene - trans-resveratrol [1]. The latter has the positive therapeutic effect on human health. The final therapeutic dose of resveratrol hasn't been established yet, however it's obvious that biologically active additives, which can be obtained using biotechnological approaches, can serve as its main source, [2-4]. In connection with this grape's tissue culture (callus and suspension) is of particular interest to biotechnological

\footnotetext{
* The reported study was funded by RFBR and Krasnodar Region according to the research project № 19-44-233006r_mol_a.

** Corresponding author: mari.sundy@bk.ru
} 
applications due to the plant's ability to accumulate and synthesize secondary metabolism compounds [5-7].

The effectiveness of the biosynthesis of biologically active substances in the cell and tissue culture depends on many factors, including the optimization of physiological processes, which promote normal growth and cell division, their differentiation and regeneration of mature plants. Biosynthesis of secondary metabolites, such as stilbenes in the grape's tissue, depends on genetic characteristics, environmental conditions and can also be induced by elicitors [8-9].

In general, an increase of stilbenes biosynthesis is associated mainly with activity and expression of stilbene synthases, however, the process of stilbenes biosynthesis of the grape's tissue and cell culture is a complex regulatory system, which involves many metabolites and phytohormones [10]. The ability of cells and tissues to maintain division and metabolism at a high level is essential too, which is associated with genotype characteristics. Stilbenes are key elements of the plant's immune response to the biotic stress [11], thus, the resistance of varieties can be associated with effective synthesis of these compounds. The aim of this study was to evaluate the connection between the tolerance of different grape varieties to downy mildew and biosynthesis of stilbenes in callus tissues of these genotypes.

\section{Materials and methods}

According to results of the study where the influence of different culture media on the callusogenesis and preservation of the culture during replantation was tested, it was revealed that the best results were obtained using M2 media with Rebrov A.N. modifications.

Callus was planted on the media patented by Rebrov A. N. for futher studies. In the current study varieties with different origin and tolerance to the downy mildew were used (Table 1).

Table 1. Resistance of grape varieties to downy mildew.

\begin{tabular}{|l|l|l|}
\hline Variety & $\begin{array}{l}\text { Downy mildew } \\
\text { susceptibility, score }\end{array}$ & Resistivity \\
\hline Aligote & 4 & susceptible \\
\hline Merlo & 4 & susceptible \\
\hline Muscat blanc & 4 & susceptible \\
\hline Vostorg & 1 & resistant \\
\hline Kober 5 BB & 0 & immune \\
\hline Krasnostop AZOS & 2 & resistant \\
\hline Dostoinyy & 2 & resistant \\
\hline Citronnyy Magaracha & 2 & resistant \\
\hline
\end{tabular}

For determining the total phenolic compounds and flavonoids (chalcones) content an extraction was conducted: $0,1 \mathrm{~g}$ of the sample was weighted with addition of $2 \mathrm{ml}$ of $95 \%$ ethanol and further incubation in the dark at a $+4{ }^{\circ} \mathrm{C}$ during night. On the next day extract was centrifuged at $15000 \mathrm{~g}$ during 15 minutes, supernatant was used for the further analysis. Determination of flavonoids content was conducted according to Chang Ch. et al. (2002). Determination of different stilbene classes (resveratrol, viniferin, piceid) in the cell extract was performed using capillary electrophoresis method on the Capel 105 capillary electrophoresis system (Lumex, Russia). Enzymatic activity of the polyphenol oxidase (PPO) was measured using catechol as a substrate according to the assay, described by Queiroz Ch. et al. (2011) [12]. PPO activity was measured by an increase of the solution's absorbtion at $420 \mathrm{~nm}$ using Unico2700 UV/VIS spectrophotometer (USA). Activity of the guaiacol 
peroxidase was measured according to Ridge I and Osborne D.J. (1971) with modifications. The repeatability for all measurements was threefold. The difference between variants was estimated using the standard error calculation. Analysis of the gene expression was conducted using real-time polymerase chain reaction (RT-PCR) on the CFX96 Touch (BioRad, USA) amplifier with application of the commercial kit qPCRmix-HS SYBR according to the manuracturer's protocol (Evrogen, Russia). Glyceraldehyde 3-phosphate dehydogenase served (GAPDH) served as reference gene. The relative gene expression level was calculated using $\Delta \mathrm{Ct}$ method (T. Schmittgen, K, Livak, 2008). Sequences of the primers used in the analysis are as follows: Chalcone isomerase (CHI) F AGACTGTGGAGGAGTTAGCG, R GAATGGAGTTGCCTGGTG [13]; Chalcone synthase (CHS) F GTTCTGGTCGTCTGCTCTG, R CCAGTCGCTGATGCCTATC [14]; Phenylalanine ammonia liase (PAL) F CCGAGCATCAACTAAATCCA, R GGCAGAGTGCCACTAGGTAT [15]; Stilbene synthase (STS) F ATCGAAGATCACCCACCTTG, R CTTAGCGGTTCG AAGGACAG [16]; Glyceroaldehyde-3phosphate dehydrogenase (GAPDH) F CCACAGACTTCATCGGTGACA, R TTCTCGTTGAGGGCTATTCCA [17].

\section{Results and discussion}

Determination of different stilbenes in grape callus showed significant differences in their ratio. The content of piceid prevailed among other stilbenes, as confirmed by the data about stilbenes distribution between different parts of the grape's tissue. Piceid is produced from resveratrol by the enzyme glycosyltransferase [18]. The majority of callus tissue samples were characterised only by a high piceid accumulation, while viniferin content was not detected (Fig. 1). Obtained results can be interpreted by considering the physiological value of piceid and viniferin in plants. According to studies of Regev-Shoshani et al. (2003), transpiceid is accumulated as a reserve form of stilbenes, which is more stable and less cytotoxic than aglycone [19]. Piceid is used in a plant as a pool for trans-resveratrol. Duan et al. (2015) proved that the majority of induced biocative stilbenes are synthesized de novo after exposure to stress conditions, rather than released from the glycosylated precursor [20].

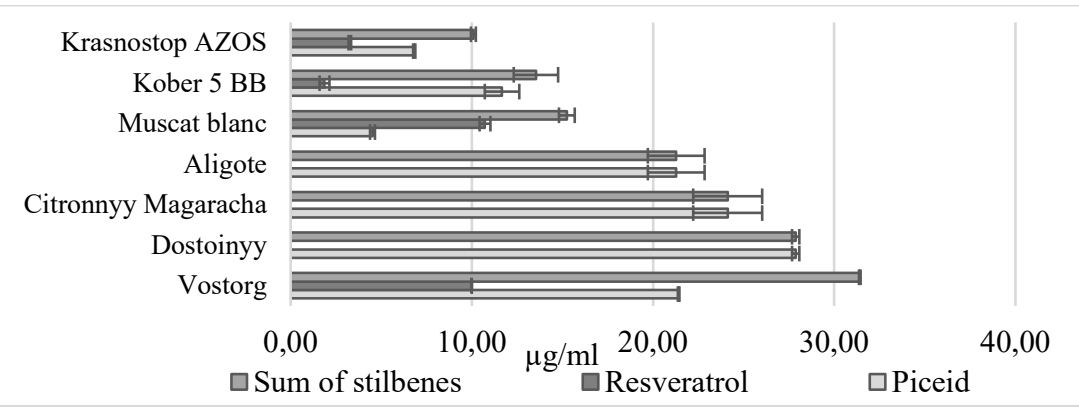

Fig 1. Stilbenes content in grape's callus.

The Vostorg variety, which is highly resistant to fungal pathogens, was characterized by a highest sum of stilbenes (resveratrol and its glycosylated form piceid). Dostoinyy and Citronnyy Magaracha varieties had the same high stilbenes content, however it was represented only by piceid. Resveratrol was detected in callus tissues of the Muscat blanc, Kober $5 \mathrm{BB}$ and Krasnostop AZOS varieties. Two varieties distinguished by the content of resveratrol, - Vostorg and Muscat blanc significantly differed in tolerance to downy mildew. Distribution of the rest varieties by total stilbenes content and their distinct fractions also didn't reflect their tolerance to downy mildew. 
Determination of phenol oxidising enzymes activity - polyphenol oxidase and guaiacol peroxidase (POX), which are some of the key elements of phenolic compounds transformation [21], didn't show any significant differences between the majority of studied callus cultures. The higher values of the guaiacol peroxidase were observed in the callus of the Muscat blanc, Citronnyy Magaracha, Kober 5BB, Krasnostop AZOS varieties. The Muscat blanc variety stood out with the highest polyphenol oxidase activity among all of experimental variants. Notably, the callus culture of the Aligote variety was characterized by a lowest enzymatic activity (Fig. 2).

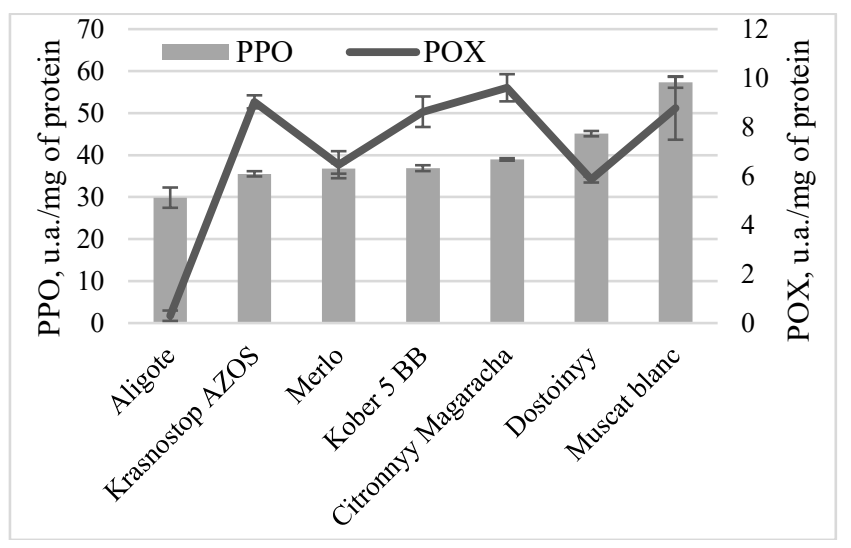

Fig 2. Activity of the polyphenoloxidase (PPO) and peroxidases (POX) in the grape's callus.

Stilbenes are produced by the condensation of one molecule of para- coumaroyl-KoA and three molecules of malonyl-CoA by the enzyme stilbene synthase. It's a proven fact that stilbene synthases evolutionally derived from the other enzyme class - chalcone synthases, which share the same substrate (Tropf S., et. al., 1994). Genes of chalcone sythases and stilbene synthases are located on same chromosomes [22]. Shared location of these genes in the plant genome results in similar regulatory elements. Thus, during stilbenes biosynthesis induction, it was found that accumulation of chalcone synthase transcripts occurs just before the synthesis initiation. It is obvious that due to the close proximity of genes and unity of the substrate, expression of chalcone synthases results in a competition with stilbene synthases and can decrease the activity of the latter [20]. Determination of differences in chalcones content in different grape varieties's callus showed that there is no interrelation between the tolerance to downy mildew and chalcone content. The highest content of these metabolites was observed in callus of the Muscat blanc and Dostoinyy varieties (Fig. 3).

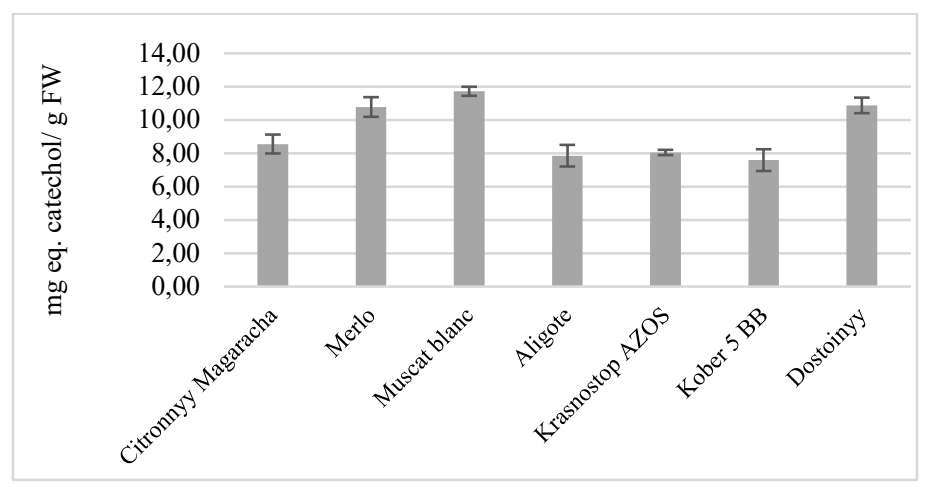

Fig 3. Chalcone content in the grape's callus culture 
Interestingly, that inter-specific hybrid varieties: Dostoinyy, Krasnostop AZOS, Citronnyy Magaracha shared the same tendency in accumulation of stilbenes and chalcones. And for $V$. vinifera varieties: Aligote and Muscat blanc the trend was in the opposite direction.

Callus cultures of the Muscat blanc variety were characterized by a high relative expression of chalcone synthase gene (CHS), chalcone isomerase (CHI) with low relative expression of phenylalanine ammonia liase (PAL), which supports the probability of competing suppression of stilbenes biosynthesis from the chalcone synthesis related enzymes during substrate deficiency. This fact is proved by a high relative content of chalcones and low stilbenes content. In general, varieties with low stilbenes synthesis in the callus culture were characterized by a low level of the PAL gene expression. Callus of the grape's varieties Krasnostop AZOS and Vostorg differed by a more high ratio of the PAL relative gene expression and lower expression ratio of chalcone isomerase (CHI), chalcone synthase (CHS) in comparison to the expression of these genes in other varieties (Fig. 4).

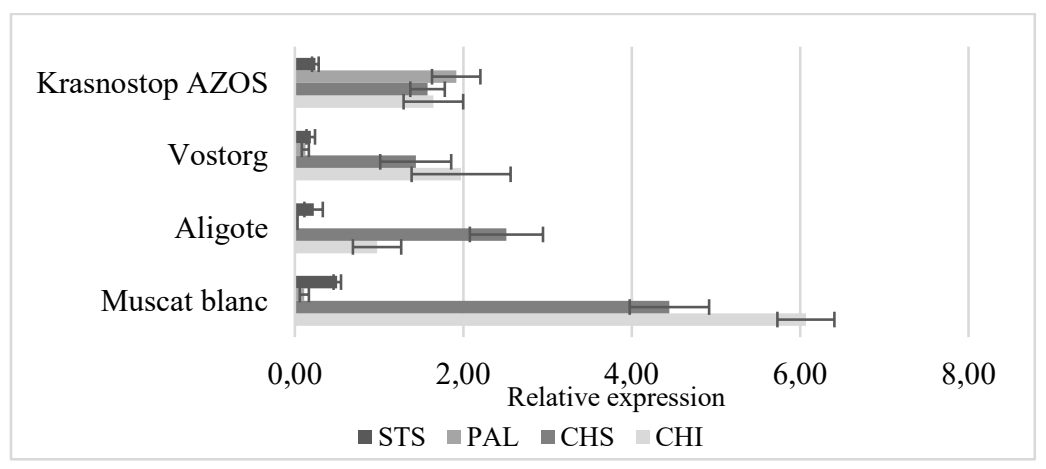

Fig 4. Expression of the phenolic metabolism genes in the grape's callus

\section{Conclusion}

Callus cultures, used in the current study, didn't show any relations between variety's tolerance to biotic stress and stilbenes biosynthesis. Stilbenes biosynthesis and expression of stilbene synthases are increasing rapidly in response to abiotic and biotic stress factors [23]. The presence of a specific stress condition for the callus culture due to its variety's tolerance may be necessary for the induction of stilbenes biosynthesis. Competing metabolic pathways of stilbenes and chalcones biosynthesis in plants, plant cell culture and tissues can suppress the production of stilbenes [20]. Obtained results showed, that varieties in which the content of stilbenes was higher, were characterized by a decline of chalcone synthase and chalcone isomerase relative gene expression compared to stilbene synthase and phenylalanine ammonia liase expression, which confirms an interrelation between a reduction in competition for the substrate between branches of chalcones and stilbenes biosynthesis with production of the latter.

\section{References}

1. Z. Zachová, J. Tříska, N. Vrchotová, J. Balík, M. Sajfrtová, H. Sovová, The J. Supercrit. Fluids, 142, 38-44 (2018) https://doi.org/10.1016/j.supflu.2018.05.021

2. F. Perez-Vizcaino, C. G. Fraga, Arch. Biochem. Biophys., 646, 107-112 (2018) https://doi.org/10.1016/j.abb.2018.03.022

3. G. Williamson, Nutr. Bull., 42(3), 226-235 (2017) https://doi.org/10.1111/nbu.12278 
4. V. Saez, E. Pastene, C. Vergara, C. Mardones, I. Hermosin-Gutierrez, S. Gomez-Alonso, M. V. Gomez, C. Theoduloz, S. Riquelme, D. von Baer, Food Chem., 265, 101-110 (2018) https://doi.org/10.1016/j.foodchem.2018.05.050

5. T. V. Vuong, C. Franco, W. Zhang, Biotechnol. Rep., 1-2, 15-21 (2014) https://doi.org/10.1016/j.btre.2014.04.002

6. L. Almagro, S. Belchi-Navarro, A. Martinez-Marquez, R. Bru, M. A. Pedreno, Plant Physiol. Biochem., 97, 361-367 (2015) https://doi.org/10.1016/j.plaphy.2015.10.025

7. T. Chastang, V. Pozzobon, B. Taidi, E. Courot, C. Clement, D. Pareau, Biochem. Eng. J., 131, 9-16 (2018) https://doi.org/10.1016/j.bej.2017.12.009

8. J. Portu, R. López, E. Baroja, P. Santamaría, T. Garde-Cerdán. Food Chem., 201, 213 221 (2016) https://doi.org/10.1016/j.foodchem.2016.01.086

9. L. Lucini, G. Baccolo, Y. Rouphael, G. Colla, L. Bavaresco, M. Trevisan. Phytochemistry, 156, 1-8 (2018) https://doi.org/10.1016/j.phytochem.2018.08.011

10. A. Vannozzi, D. C. J. Wong, J. Höll, I. Hmmam, J. T. Matus, J. Bogs, M. Lucchin. Plant Cell Physiol., 59(5), 1043-1059 (2018) https://doi.org/10.1093/pcp/pcy045

11. S. Boso, V. Alonso-Villaverde, M. Martíne, H. Kassemeyer. Am. J. Enol. Vitic., 63(3), 419-423 (2012) https://www.researchgate.net/profile/Boso_S/publication/272773482_ Quantification_of_Stilbenes_in_Vitis_Genotypes_with_Different_Levels_of_Resistanc e_to_Plasmopara_viticola_Infection/links/5576e9e508ae7521586e0c71.pdf

12. C. Queiroz, A. J. R. da Silva, M. L. M. Lopes, E. Fialho, V. L. Valente-Mesquita. Food Chem., 125(1), 128-132 (2011) https://doi.org/10.1016/j.foodchem.2010.08.048

13. S. Niu, F. Hao, H. Mo, J. Jiang, C. Liu, H. Wang, Acta. Physiol. Plant. 39, 171 (2017) https://doi.org/10.1007/s11738-017-2473-y

14. H. Wang, W. Wang, J.-Ch. Zhan, A. Yan, L. Sun, G. Zhang, X. Wang, J. Ren, W. Huang, H. Xu, Plant Physiol. Biochem., 106, 165-176 (2016) https://doi.org/10.1016/j.plaphy.2016.04.042

15. L. Villalobos-Gonzalez, A. Pena-Neira, F. Ibanez, C. Pastenes, Plant Physiol. Biochem., 105, 213-223 (2016) https://doi.org/10.1016/j.plaphy.2016.04.012

16. M. C. Dufour, C. Lambert, J. Bouscaut, J. M. Merillon, M. F. Corio-Costet, Plant Pathol., 62(2), 370-382 (2013) https://doi.org/10.1111/j.1365-3059.2012.02628.x

17. W. Dumin, M. Rostas, C. Winefield, Mol Biol Rep, 45, 263-277 (2018) https://doi.org/10.1007/s11033-018-4159-y

18. H. Boubakri, A. Poutaraud, M. A. Wahab, C. Clayeux, R. Baltenweck-Guyot, D. Steyer, C. Marcic, A. Mliki, I. Soustre-Gacougnolle, BMC Plant. Biol., 13, 31 (2013). https://doi.org/10.1186/1471-2229-13-31

19. S. M. Yu, H. K. Lee, U. S. Jeong, S. H. Baek, T. H. Noh, S. J. Kwon, Y. H. Lee, Hoon Res. Plant Dis., 19(3), 177-182 (2013) http://dx.doi.org/10.5423/RPD.2013.19.3.177

20. D. Duan, D. Halter, R. Baltenweck, C. Tisch, V. Tröster, A. Kortekamp, P. Hugueney, P. Nick, J. Exp. Bot., 66(11), 3243-3257 (2015) https://doi.org/10.1093/jxb/erv137

21. Y. Zhou, Z. Yang, L. Gao, W. Liu, R. Liu, J. Zhao, J. You, JGR, 41(3), 307-315, (2017) https://doi.org/10.1016/j.jgr.2016.06.001

22. K. V. Kiselev, O. A. Aleynova, App. Biochem. and Micr., 52(1), 56-60 (2016) https://www.elibrary.ru/item.asp?id=26927543

23. I. Souid, I. Toumi, I. Hermosin-Gutierrez, S. Nasri, A. Mliki, A. Ghorbel, Physiol. Mol. Biol. Plants, 25, 625-635 (2019) https://doi.org/10.1007/s12298-019-00668-2 